\title{
The Implementation of Culture and Literature through Mambere Tungkot in Simalungun Batak and Mere Ciken in Karo Batak: The Local Wisdom Maintenance
}

\section{Martina Girsang and Milisi Sembiring}

Methodist University of Indonesia

\section{Abstract}

Mambere Tungkot, Duda-Duda, and Sulang Sulang Pahompu (MTDSP) and Mere Ciken ras Tuk-Tuk (MCT) are two forms of traditional ceremonies from Simalungun Batak and Karo Batak Tribes as the local wisdoms. Eventhough the terms are different, they have some similarities purposes. MTDSP and MCT are the traditions which are organized by children and grandchildren toward their parents as the forms of respect

Corresponding Author: Martina Girsang martinagirsang253@gmail.com

Received: 13 March 2018 Accepted: 10 April 2018 Published: 19 April 2018

Publishing services provided by Knowledge

(c) Martina Girsang and Milisi Sembiring. This article is distributed under the terms of the Creative Commons

Attribution License, which permits unrestricted use and redistribution provided that the original author and source are credited.

Selection and Peer-review under the responsibility of the AICLL Conference Committee.

\section{G OPEN ACCESS} and appreciation whom had guided, educated, and given them good lives. In gathering the data, the researcher uses descriptive qualitative method. The objectives of the study are to construct the implementation of literature, such as umpasa 'poem' and umpama 'proverb' and anding andingen 'proverb', philosophy, then to analyze them by conducting hermeneutics theory and methology. The implementation of the roles of the Tolu Sahundulan (the kindships in Simalungunese clan), and the Rakut Sitelu (the kindships in Karonese clan) can be seen through the MTDSP and MCT; how the children and the grandchildren show their love, appreciation, and care toward their parents. By keeping do both the MTDSP and MCT, the local wisdoms from Simalungun, and Karo are still maintained.

Keywords: culture, literature, local wisdom, mambere tungkot, mere ciken.

\section{Introduction}

Indonesia as a big country has thousands variation of ethnicities that be the characteristics, and the pride as well. One of the ethnics is Batak tribe which is located in North Sumatra Province. The Batak consists of: Toba Batak, Simalungun Batak, Karo Batak, Mandailing Batak, Angkola Batak, Pak-Pak Batak.

Linguistically all the Bataks have relationship in the implementation of both the culture and literature, for each of them still have kindship tightly from one generation to the other ones. In Karonese tribe according to Sembiring (2015)" there is Daliken 
Sitelu or Rakut Sitelu that consists of Sembuyak as the ruler; Anak Beru as the server, and Kalimbubu who is served". In Simalungunese society there is also the kindships tight that is called Tolu Sahundulan which consists of Sanina as the ruler, Anak Boru as the server, and Tondong be served. They have one organic system that can not be aparted one to another. The three systems of the society based on the sombah martondong means respect to the uncle, elek marboru means be patience to the inlaw, manat marsanina means keep guarding the brotherhood. Girsang (2005). Through the traditional events, it can be seen the cultural systemic bond that indicates the position of the kindships.

Mambere Tungkot, Duda-Duda, and Sulang-Sulang Pahompu (MTDSP) from Batak Simalungunese, and Mere Ciken ras Tuk-Tuk (MCT) from Batak Karonese are two forms of traditional ceremonies. Terminology MTDSP and MCT are different, and both of the societies are influenced by the territorial area, but, basically, they have some similarities in the implementing the culture and the literature. The ceremonies are organized by children and grand children as the forms of their respect and appreciation toward their parents who had borned, cared, loved and struggled them into a good living.

In Simalungunese tribe the forms of the respect, and the appreciation can be seen by giving a tungkot 'a stick' to their father,giving a duda-duda 'a mixer for betel leaf' to their mother; dressing their father with a set of new shirt n suit, gotong 'a kind of hat'; dressing their mother with a set of kebaya and bulang 'a kind of hat for a woman'; serving their parents with a special food such as dayok na binatur 'a cock is cut then is cooked so that is compiled on a pinggan pasu'a kind of plate that is special used for the dayok na binatur. Sumbayak (2001: 46-55); In Karonese tribe the forms of the respect and appreciation are similar, such as the ciken 'stick' is given by the children toward their father, in this case it is represented by the first son, and tuk-tuk 'a mixer for betel leaf' is given to their mother by the daughter inlaw. Both the parents are dressed with a set of new dress,such as: bulang bulang beka buluh 'a kind of hat', baju gunting cino 'a set of coats' for the father; Then the children give some materials to their mother, such as: Uis batu jala or kelam-kelam 'is formed be a hat', uis nipes 'a kind of shawl', gonje 'a set of women's clothing', then all of them have lunch together. (Sitepu, 1995: 69-71)

In implementing the culture and the literature through the MTDSP and the MCT indeed there must be needed communication as the tool of conveying the messages of the traditions. As Kreidler (2002: 176) said that communication is an act, a series of elements with purpose and intention. 
Based on the above idea, in these studies it needs someone who runs the chronology of the ceremonies well, such as: a good parsahap 'a speaker' in Simalungunese, and anak beru jabu pengerana in Karonese who guide all the kindships'role to act and to talk by implementing the culture and the literature elements such as umpasa 'poetry' and umpama 'proverb'; anding andingen 'proverb' or symbols. Through the implementations, the messages of the traditions are delivered to all the kindships and visitors.

This research used a qualitative one since the data will be ordinarily expressed in qualitative terms, for the data analysis will not be employed in hypothetical test. In conducting the scientific research, the systemic steps of collecting the data were carried out by interviewing, library, and internets.

In constructing and in analyzing the data in these studies, the writer uses the Hermeneutics as both the theory and the methodology for according to Eagleton (1983: 71-72), it describes the process, and the running of understanding the biblical texs, wisdom literature, and philosophical texts.

\section{Literature Review}

There are some Mambere Tungkot Pakon Duda Duda and Mereken Ciken ras Tuk-Tuk researchs done by people, but among them, the writer finds no single research about the Implementation of Culture and Literature Through Mambere Tungkot, Duda-Duda and Sulang-Sulang Pahompu in Batak Simalungunese and Mere Ciken ras Tuk Tuk in Batak Karonese: Local Wisdom Maintenance, but the followings:

- Girsang, Chris. Nilai Mambere Tungkot Pakon Duda Duda Suku Batak Simalungun Ditinjau dari Teori Konfigurasi Nilai Nilai Kebudayaan 'The Value of Mambere Tungkot Pakon Duda Duda in Batak Simalungun Tribe based on the Culture Value Configurative Theory'

It analyzes the value of the Simalungunese tribe traditional that still exist from one generation to the present time as the form of respect, and appreciation toward parents.

- Digilib.unimed.ac.id. Tradisi Mambere Tungkot dan Duda Duda Pada Etnis Simalungun Di Pematang Raya Kecamatan Raya Kabupaten Simalungun' Mambere Tungkot dan Duda Duda Traditional in Simalungun Tribe in Pematang Raya Sub District Raya Simalungun Regency. 
It analyzes the tradition of the Simalungunese society to respect parents who have been mature and it through the tradition people can see the kindships role.

- ttarigan.blogspot.com. Mereken Ciken ras Tuk-Tuk' Giving a Stick and a Mixer'

It analyzes the tradition in karonese tribe as the form of respect done by children toward their parents.

\subsection{Definition of literature}

There are some definitions about literature, such as according Eagleton (1986: 2) 'Literature transforms and intensifies ordinary language, deviates systematically from everyday speech'.

Literature consists of three genres, such as: prose, poetry, and drama. In this study, the writer takes the written and oral literature through poetry as the form of implementation. In the poetry, it can be found some symbols or the figurative language. Wiiliam Wordsworth said that poetry is the spontaneous overflow of powerful feelings.

Based on the definitions above, the writer relates the poetry with the umpasa and umpama in Simalungunese, and the anding-andingen in Karonese.

\subsection{Umpasa}

According Tarigan (1880) Umpasa adalah puisi rakyat yang dipergunakan dalam masyarakat Simalungun dalam berbagai kegiatan kebudayaan, seperti pernikahan, kematian, dan acara adat lainnya' Umpasa is the folk poem that is used in the Simalungunese tribe through many kinds of traditions, such as wedding party, funeral, and others traditional activities'

\subsection{Umpama}

Umpama is different with umpasa. Umpama is a proverb that contains the general truth' picture, or normally is called as the philosophy of life. Sigotom (2017)

\subsection{Anding-andingen}

Anding-andingen is a proverb in Karonese tribe that describes someone to the picture of a thing. 


\subsection{Definition of Hermeneutics}

According to Rafiek, M (2010: 3-4) "Hermeneutics is a theory about an understanding of text interpretation. It compiles the exegesis by interpreting a particular text or about the analyzing process of a content, and a hiding meaning, such as symbol. mythos in a society or a litrary work"; According to Heidegger (in Eagleton (1983: 71-72), Hermeneutics describes the process, and the running of understanding the biblical texs, wisdom literature, and philosophical texts.

\section{Research Method}

The research in this study used the qualitative since the data will ordinarily expressed in qualitative terms. Besides, this is because the analysis will not be hypothetical test. The objectives explanative are the suitably fixed design of this research. The decision of determining of sort of this research design is highly dependent on the nature of the research, that are, to objectively construct, descript and analyze by the interpreting the Implementation of Literature through Mambere Tungkot, Duda-Duda, and SulangSulang Pahompu (MTDSP) from Batak Simalungunese, and Mere Ciken ras Tuk-Tuk (MCT) from Batak Karonese: Local Wisdom Maintenance by using the Hermeneutics theory and method.

\subsection{The subject of the studies}

The subjects of the studies are parsahop 'speaker' in Simalungunese, and pengerano 'speaker' in Karonese (who have chosen by the children) in categorized as the data in this research. Data are defined as the raw materials collected by the researchers from the world they are studying; they are the particular that form the basis of the the analysis (Bogdan, Biklen 1992: 106). The data will get from the context,the communication or the conversation of the kinships role each in the tradition. Then the data will be recorded in order that the communication or the conversation can be analysed further. 


\section{Discussion}

\subsection{Mambere tungkot duda duda and Sulang Sulang Pahompu (MTDSP) in Simalungunese}

The MTDSP is a traditional ceremony in Batak Simalungun tribe that organized by children, and grandchildren as the form of their respect and appreciation toward their parents. The ceremony is held when the parents are old, and the childrend had got married all. Normally, the childrend held the MTDSP when they have good living for the MTDSP needs lot of money to spare.

A. There are some materials to prepare for the MTDSP, such as:

1. a set of cloth for the father (suit suits and shirt, tie, gotong 'a kind of hat', hatirongga 'a kind of ulos', suri-suri 'a kind of shawl', and a tungkot 'a stick'.

2. A set ofclothing for the mother (akebaya, bulang 'a kind of hat for a woman', hati rongga 'a kind of ulos', suri suri 'a kind of shawl', bajut and duda duda 'a media to place battle leaves and a mixer for the battle leaf'.

3. a mattress for the parents to sit in, tobu sigerger with the root, leaf, and flower 'red cane', rondang ni omei 'the grain of rice'.

4. Namalum 'lard', nitak siang-siang 'cake made of rice flour', banana, boiled egg.

5. Dayok binatur 'a cook chicken compiled on a plate', and dengke sayur 'one cook fish on a plate'.

6. Some coins, some foods for lunch

B. Preperation of the implementation

1. Core family deliberations

2. Socialization of the MTDSP and the meaning

3. Discussing about how much will be the invitation

C. The cernomy will be held in the morning (it is the symbol of spirit)

\subsection{Mereken Ciken ras Tuk-Tuk (MCT) in Karonese}

The MCT is held by children and grand children toward their parents as the form of their respect and appreciation. Almost similar with MTDSP in Simalungunese tribe, in 
Karonese tribe the ceremony is held when the parents are old, and the childrend had got married all. Normally, the childrend held the MCT when they have good living for the it needs lot of money to spare.

A. There are some materials to prepare for the MCT, such as:

1. Ingan kundul orang tua em amak cur 'seating mat for the parents'.

2. Ciken 'a stick' for the father, Tuk Tuk 'a mixer for the battle leaf'

3. Dressing the father with a bulang beka buluh 'a kind of hat for a man', baju gunting cina, normally it consists of suit and shirt, tie, Uis langge langge, uis pementing, cengkuk cengkuk, uis batu jala

4. Dressing the mother with tudung batu jala or kelam kelam 'a kind of hat made of uis', uis nipes 'a kind of shawl', gonjena sambat-sambat 'the skirt', kebaya'shirt'.

5. Eatng lunch

B. Preperation of the implementation

1. Core family deliberations

2. Socialization of the MCT and the meaning

3. Discussing about how much will be the invitation

C. The cernomy will be held in the morning (it is the symbol of spirit)

\subsection{The implementation of culture and literature through MTDSP and MCT}

A. MTDSP

1. Before starting the tradition, all the kinships, children, grand-children take and give the battle leaves each other for the sake of the tradition ceremony runs well.

2. Then, pray to God that He bless the tradition step by step smoothly.

3. The grandpa is bathed by a grand son and the grandma is bathed by a grand daughter. Both the grandpa/ma marpangir utei mungkur 'are shampooing with lime woter'.

The untei mungkur 'the lime'is the symbol of throwing all the bad thinking and send away the demonic power. In this session the grand children convey many 
pray and wish that the grandpa/ma want to firm and calm their heart and mind, and thank them who have borned, educated, cared, and love their father or mother.

4. The grand pa/ma are dressed with the prepared dresses the previous time, then sitated them on the pallet.

5. The grand son and grand daughter and children give na malum 'lard' toward the grand pa/ma by saying their wish that the grandpa/ma are always be healthy and happy.In addition, they ask for the grand pa/ma to forgive them all if they made mistakes at the previous time.They also ask for the grandpa/ma blessing them,so that they will get a better life for their future.

The umpasa 'poem': Gonrangni Simalungun 'The Simalungunese drum'

Tortorni haro-haro 'the dance is haro-haro'

Lagu selayang pandang 'the song is selayang pandang'

Sai daohma hu lobeian on namalungun' hope the sadness will go away'

Sonai ge uhur na mambahen uhur haru'the suffering goes either'

Sai jorgitma ganup pamatang 'be good and safe'

From the umpasa 'poem' above it can be seen that the two verses have good rhyme, aaaaa; the first two lines are the hang or the couplet, the third and the fourth lines are the cores of the poem; there are good message about hope to strengthen the people.

6. After giving the na malum toward the parents, the children and the grandchildren give dayok binatur.

The dayok binatur is a symbol of regularity, discipline, faithful, responsible, brave, and clean. Thatswhy the children and the grandchildren ask for the grand pa/ma keep bringing them in the prayer, so they can take the philosophy life of the dayok binatur. In this case it can be seen the using of umpama 'proverb'. After accepting the dayok binatur the grand pa/ma will say the following proverb: sai lambin taratur ma goluh nima hu lobeian ni ari on, lambin ringgasni marhorja, songon partaraturni dayok na binatur on 'you have to work harder, and your life is better and more organized forward like the life of the rooster'.

7. Giving the duda-duda 'the battle leaf's mixer) to the grand ma.

In this session, all the grand childrend mix the battle leaves, then give it to the grandma to eat, and she will bless them all who have make her easier to eat. It shows the care and the love of the grand children toward the grandma. 
8. Giving Tungkot'stick' to the grand pa.

The stick is the symbol of a guide. Though the people trust that main guide is God by His words. In this session the stick is represented by a red cane. The children give it to the father by conveying some proverbs, such as:" father, we give this red cane for you as a stick. We wish our life is as sweet as this sugar, so we share the blessing to other people".

After that the grand children give the real stick to the grand pa and ask for him to sit down again.

9. The grandpa/ma sow the rice, coins, and peaces of the red cane.

In this session the grand $\mathrm{pa} / \mathrm{ma}$ sow the rice, coins, and pieces of red cane to show the result of their pray in their live. Beside that, the grand pa/ma give ulos to each of their children, though the ulos are prepared by the children. The grand $\mathrm{pa} / \mathrm{ma}$ also advice the children, and the grand children to respect all the kinships, friends and other people like this:

Buat sada kedondong 'take a kedondong'

Etek pe tong matobu 'though it is small but sweet'

Anggo kedonnong luna 'if kedondong luna'

Dabuh do anggo udan'will fall at the rain'

Hormat ma bani tondong'respect to the tondong 'one of the kinship, $\mathrm{s}$ role'

Elek homa marboru 'be patient to the boru'the inlaw'

Anju bani sanina 'discuss always with sanina 'brother'

Se siat bani humpulan 'so that you will be accepted by the people'

The other one:

Lak lakni Tamba Tua, hoppa mambuat kuah 'the skin of Tamba Tua, carrying the sauce

Pasangap orang tua, tong tong dapotan tuah 'respect your parents, you will always get blessing'.

From the first above umpasa it can be seen the using of provers, the symbols, and the rhymes are aaaa; the first, second, third, and fourth lines are the couplet of the poeb, the fifth, sixth, seventh, and eighth are the cores of the poem. It can be seen the philosophy message of the umpasa that the the grand $\mathrm{pa} / \mathrm{ma}$ convey advice how to involve in the society. 


\section{B. MCT in Karonese}

In this tradition there is no poem or poetry implementation, but proverb only which is called anding-andingen. It can be seen by the following steps in the tradition:

1. The parents to be to sit on a mat that is spread before, then all the children, grand children come to them bringing kampil 'the media for the battle leaves', bringing tudung 'the hat for the grand ma', bringing bulang 'hat for the grand pa', bringing ose 'cloths for the grand pa and grand ma'.

2. The eldest daughter inlaw makes a speech by saying: Ibas nangkih nangkih matowari enda pulung kami kerina permendu ras anakndu o bibi, nina bengkila. Isembahken kami menda belo cawir maka cawirlah kam duana, entah ija gia sekali kurangna pembahanan kami, mindo ngenda anak ras permendu maka ola tamo sangkut ukurndu, Meriahlah ukurndu ngalo ngalokerehen kami kerina sebab kamilah kerina tuah ras kebayakendu. 'In this sun rises time, we are all your children and daughter inlaw come to you to bring the battle leaves, so you bless us all that getting a more beautiful life. We also ask for your forgiveness if we made wrongs for we are all your welth 'Through this speech it can be seen the using of proverbs, such as Ibas nangkih nangkih matowari' this sun rises', belo cowir"fresh betel leaf'. Both the proverbs are the symbols of hope for the rising of the children's good healty, and good life.

3. Acara ngampeken tudung ras bulang'the ceremony of putting the hat on the father and mother's heads'

The bulang is put on the father's head done by his eldest son, and the tudung 'hat' put on the mother's head done by the eldest daughter inlaw. Then the son makes a speech as following:

I tampeken kami menda bulang ras tudung ku takalndu bapa ras nande gelah tampelah kini tuah, kini sangap, kini bayak man kami kerina anakndu, man kalimbubu, man kerina anak beru, cawir kam metua, ola sakit sakit 'we put these bulang and tudung on your heads both father and mother, so that we will get blessing, wealth, pride for us all your children, all the kinships. Be good and safe father and mother'.

Through the son's speech, it can be seen the using of proverbs by many symbols, such as bulang ras tudung' hat for the father and mother'. Both the bulang ras tudung are always put on the head (the toppest part of the body).

4. Mere ciken ras Tuk Tuk 'giving a stick and a battle leaves mixer' 
In this session the eldest son gives the stick to his father, and the eldest daughter inlaw gives the mixer to her mother inlaw as the forms respect and appreciation. Then the son makes a speech, as follows:

Ibas wari simehuli, I adepan kerina kalimbubu, senina ras kalimbubu, ersura sura menda kami nande ras bapa, erkiteken daging ibabandu nggo metua, ate kami ibereken kami tuk tuk ras ciken bandu, eme ciken pegegeh kulandu gelah kam megegeh cawir metua. Ciken enda iban gelarna ciken pangguh maka meteguhlah pertendindu, enteguh pertendin kami bagepe karina sangkep ngeluh. Ciken enda ciken entebu, maka entebulah kerina pergeluhenta, pendapatenta. Enda ka tuk tuk nande gelah ula mesera kam erbelo, kami pe kerina ula mesera pergeluhen kami 'In this beautiful momen we are your children wish to give a stick to you our father, and battle leaves miver to you our mother. In front of all our kinships we gave these for you both as the form of our respect and appreciation. Both of you are old enough, so please have these stick and mixer, and bless us to have more pride, wealth, and good healthy'.

\subsection{The contributions of the MTDSP and MCT towards the people and the local wisdom}

Through the implementation of the cultere and literature that have been discussed above, there are some contributions of the MTDSP and MCT toward the people and the local wisdom, such as:

1. Both the traditions send moral lessons toward people how to respect and to appreciate parents who have stuggled for their children till they got better lives.

2. Both the traditions educated people how to work together in preparing and celebrating an event.

3. Both the traditions introduced people the raw materials of the traditions

4. Both the traditions add the local wisdoms in our country, Indonesia, as the wealth and the pride that need to be maintained.

\section{Conclusion}

After describing, constructing, and analyzing the Implementation of the culture and the literature through the MTDSP and MCT: local wisdom maintenance, the writer 
comes into the conclusions that: Both the MTDSP from Simalungunese, and the MCT from Karonese are two forms traditional ceremonies that held by the children and grand children as the forms of respect and appreciation toward their parents; Both the MTDSP from Simalungunese, and the MCT from Karonese are two forms traditional ceremonies that the culture and literature were implemented. They can be seen by the implementation of the elements of the literature, such as: umpasa, umpama, andingandingen, and philosophy; Both the MTDSP from Simalungunese, and the MCT from Karonese are two forms traditional ceremonies that contribute some moral lessons, mutual cooperation that are very important for the people and the local wisdom, especially for anticipating the globalization era currently.

\section{References}

[1] Eagleton, T. (1983). Literary Theory an Introduction. padstow: T.J. Press Ltd.

[2] Girsang, c. (n.d.). Nilai mambere tungkot pakon Duda-Duda suku Batak Simalungun Ditinjau dari Teori Konfigurasi Nilai-ilai Kebudayaan. Electronic Thesis Disertation.

[3] Girsang, D. (2011). Tradisi Mambere Tungkot dan Duda-Duda Pada Etnis Simalungun di Pematang Raya, Kecamaton Raya, Kabupaten Simalungun. Medan: Desy Girsang.

[4] Girsang, M. (2005). Ragam Bahasa dalam adat Perkawinan Simalungun. scholar.google.co.id.usu repository.

[5] Kreidler, C. (2002). Introducting to Englissh Semantics. New York: Taylor and Fransis E-Library.

[6] Rafiek, M. (2010). Teori Sastra Kajian Teori dan Praktek. Bandung: Refika Aditama.

[7] Sembiring, M. (2015). Translating Daliken Sitepu Texts in Karonese Society into English. USA: Lulu Press Inc.

[8] Sitepu, A. G., Ginting Suka, A., Sitepu, B., Ginting, H. M., Sinulingga, I., Sukapiring, P., et al. (1995). Adat Nggeloh Karo Kenjulu. Berastagi: Panitia Kongres Kebudayaan Karo.

[9] Sumbayak, J. (2001). Refleksi Habonaron do Bona Dalam Adat Budaya Simalungun. Pematang Siantar: Japiten Sumbayak.

[10] Tarigan, H. g. (1980). Perbandigan Umpasa Simalungun dengan Pantun Mealyu. Jakarta: Proyek Penerbitan Buku Sastra Indonesia dan Daerah.

[11] Tarigan, T. (2011, 10 13). Kao Simalem. Retrieved 1 15, 2018, from Karo Simalem: http://ttarigan.blogspot.co.id/

[12] Wordsworth, W. (1962). Lyrical Ballad. England. 